\title{
Endobronchial Lipoma
}

National Cancer Institute

\section{Source}

National Cancer Institute. Endobronchial Lipoma. NCI Thesaurus. Code C5063.

A rare benign adipose tissue neoplasm located within the lumen of a bronchus. It is predominantly found in males and usually orig inates within the fatty tissue between bronchial cartilage. May cause irreversible pulmonary damage distally. Two-thirds of the tumors occur on the right side and most are located on the first three subdivisions of the tracheobronchial tree. 